\begin{tabular}{|c|c|}
\hline & $\begin{array}{c}\text { International Journal of Current Research } \\
\text { and Academic Review }\end{array}$ \\
\hline & 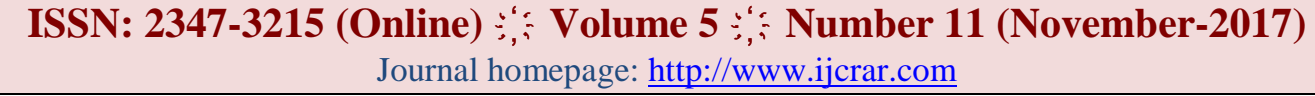 \\
\hline
\end{tabular}

doi: https://doi.org/10.20546/ijcrar.2017.511.009

\title{
Biodegradation of Domestic Waste Water using Fresh Water Thermophilic Fungi Isolated from Mayanur Dam, Tamil Nadu, India
}

\author{
R. Anbalagan and R. Sivakami* \\ Department of Zoology, Arignar Anna Govt. Arts College, Musiri-621211, Tamil Nadu, India \\ *Corresponding author
}

\section{Abstract}

Fungi have been reported to play an important role in bioremediation processes. Hence the study was attempted using fungi to analyse the bioremediation effect. Results show that $\mathrm{pH}$ levels were found to decrease between 7.3 to 7.8 while nitrate levels decreased between 69.9 to $84 \%$ and phosphates between 79.2 to $83.4 \%$. The BOD and COD levels showed reduction between 78.6 to $89.4 \%$ (BOD) and 82.6-85.6\% (COD). Nevertheless, the maximum reduction was noticed in the setup which contained the consortium of organisms probably showing a synergistic effect.

\section{Article Info}

Accepted: 28 October 2017

Available Online: 20 November 2017

\section{Keywords}

Bioremediation, Thermophilic Fungi, Domestic Waste Water

\section{Introduction}

It is a well-known fact that aquatic fungi play an important role in degradation by secreting enzymes that degrade polysaccharides and polymers (Suberkropp and Klug, 1980; Singh, 1982; Chandrashekar and Kaveriappa, 1988; Sangar Rao, 2013).

Fungi are also efficient in degradation of recalcitrant compounds by their extracellular lignolytic enzyme system (Boulanger et al., 2010).

In addition, literature also reveals that fungi can play a role in biosorption of toxic compounds during waste water treatment (Cooke, 1976; Kshirsagar et. al., 2012; Sivakamiet al., 2014; Smily, 2016).

Hence the present study was aimed at using commonly occurring fungal species to assess their degrading ability.

\section{Materials and Methods}

\section{Collection of waste water}

The domestic waste water samples used in this study were collected from Musiri area, Tiruchirappalli District, Tamil Nadu, India.

\section{Analytical Methods}

The waste water samples were analysed for $\mathrm{pH}$ using a $\mathrm{pH}$ meter. The biochemical oxygen demand (BOD), chemical oxygen demand (COD), phosphate and nitrate were determined as per standard methods (APHA, 1998).

\section{Microorganism Selection}

The fungi used in this study were isolated from water from the River Cauvery at Mayanur Dam, Karur District, 
Tamil Nadu. The experiments described in this study were carried out using four different species of fungi (Aspergillus fumigatus, Rhizopus funiculosum, $R$. stolonifer and Fusarium oxysporum) for the treatment of waste water.

\section{Fungal Medium Culture}

For isolation of fungi from the polluted water, PDA and malt extract broth medium were used. The pure fungal cultures were inoculated and grown in the test tube containing PDA medium maintained at $4{ }^{\circ} \mathrm{C} .100 \mathrm{ml}$ of malt extract broth (MEB).MEB was prepared and dispensed into $250 \mathrm{ml}$ conical flasks. On cooling, a loopful of individual fungal stains was inoculated in MEB under sterile condition and kept at $25-27^{\circ} \mathrm{C}$ for 7 days on a rotary shaker at $100 \mathrm{rpm}$.

For experimental purposes, cultures were pre pared using mycelia from shaker flasks. The mycelium culture was pre-treated by homogenization at maximum speed (3000 $\mathrm{rpm}$ ) for $3 \mathrm{~min}$. After that, the whole mass was mixed in a blender to make a homogenous mixture. In order to obtain sufficient biomass for the subsequent growth and waste water treatment experiments, all the fungi were cultured in MEB and grown for a week before using for the experiment.

\section{Experimental Set-up}

The selected species of fungi were used for waste water treatment. The waste water samples collected from Musiri area, Tiruchirappalli District were used for the fungal assays. The waste water was filtered using Whatman No.1 filter paper to remove suspended solid particles.

To study the role of fungi in waste water treatment, the waste water was treated with selected species of fungi. Waste water without fungi was used as a control. Experiments were conducted intriplicates. Flasks with $200 \mathrm{ml}$ of waste water were used for the treatments. Two $\mathrm{ml}$ of uniform suspension of Aspergillus fumigatus, Rhizopus funiculosum, Rhizopus stolonifer and Fusarium oxysporum were used as initial inoculums (7 day sold culture) in each of the four flasks.

The experiment was conducted for a total duration of 16 days within a temperature range of $30 \pm 2^{\circ} \mathrm{C}$. Samples were periodically (every 4 days) analyzed for physicochemical parameters such as $\mathrm{pH}$, phosphate, nitrate, BOD and COD using standard methods (APHA, 1998).

\section{Results and Discussion}

The results of the various parameters that were assessed are present in Tables 1-5.Table-1 records the influence of fungi on $\mathrm{pH}$ levels for a period of 15 days. As evident from the table, all the four fungi used in the study showed a decrease in the $\mathrm{pH}$ level. Among the fungi, Penicillium funiculosum recorded maximum reduction in $\mathrm{pH}$ (7.6). Nevertheless, it was the consortium of all the four fungi that recorded the maximum reduction in $\mathrm{pH}$ (7.39). Further, all the fungi including the consortium of fungi showed a decreasing level of $\mathrm{pH}$ on all the experimental days.

The effect of fungi on the $\mathrm{NO}_{3}$ levels are presented in Table-2. As evident from the table, among the four fungi, Aspergillus fumigatus recorded maximum reduction in $\mathrm{NO}_{3}$ level (84.0\%) followed by Fusarium oxysporum. However, here also, it was the consortium of fungi that recorded the maximum reduction in nitrate level (86.4\%). Here also all the fungi including the consortium continuously showed decreasing $\mathrm{NO}_{3}$ level on all the days of the experiment.

The effect of fungi on phosphate removal are presented in Table-3. The table clearly shows that Fusarium oxysporum recorded maximum reduction in phosphate level $(84.6 \%)$. The consortium also showed the same amount of phosphate reduction as Fusarium (84.6\%). However, here also all the groups showed reduction till the last day of study.

The effect of fungi on BOD and COD are presented in Tables-4 and 5. It is clear that all the experimental groups showed a continuous decrease in both BOD and COD level on all the days of assessment. However, while A. fumigatus recorded a maximum decrease in BOD level (89.4\%), it was $F$. oxysporum that recorded maximum decrease in COD level (85.6\%). However, it was the consortium of fungi that recorded maximum decrease in both BOD (89.9\%) and COD levels (87.6\%).

A perusal of literature reveals that Sivakami et al., (2014) also recorded a decrease in $\mathrm{pH}$ levels ranging from $8.16-8.89 \%$ using various fungi. However, they recorded maximum reduction levels in the set up containing A. niger, in the present study, the maximum reduction in $\mathrm{pH}$ was recorded by $P$. funiculosum followed by A. fumigatus. Further, while they noted a decrease in $\mathrm{pH}$ level only till the 12th day, the present study recorded a continuous decrease till the 15th day of study. 
Table.1 Variation of $\mathrm{pH}$ content among the various experimental setups

\begin{tabular}{|c|c|c|c|c|c|c|}
\hline Days & Control & $\begin{array}{c}\text { Aspergillus } \\
\text { fumigatus }\end{array}$ & $\begin{array}{c}\text { Penicillium } \\
\text { funiculosum }\end{array}$ & $\begin{array}{c}\text { Rhizopus } \\
\text { stolonifer }\end{array}$ & $\begin{array}{c}\text { Fusarium } \\
\text { oxysporum }\end{array}$ & $\begin{array}{c}\text { Consortium } \\
\text { Fungi }\end{array}$ \\
\hline 0 & 8.25 & 8.25 & 8.25 & 8.25 & 8.25 & 8.25 \\
\hline 3 & 8.00 & 7.92 & 7.91 & 8.20 & 8.10 & 7.90 \\
\hline 7 & 7.90 & 7.86 & 7.88 & 7.92 & 7.80 & 7.62 \\
\hline 11 & 8.00 & 7.76 & 7.72 & 7.70 & 7.72 & 7.76 \\
\hline 15 & 8.10 & 7.71 & 7.60 & 7.84 & 7.76 & 7.39 \\
\hline
\end{tabular}

Table.2 Variation in $\mathrm{NO}_{3}$ content among the various experimental setups

\begin{tabular}{|c|r|r|r|r|r|r|}
\hline Days & Control & $\begin{array}{c}\text { Aspergillus } \\
\text { fumigatus }\end{array}$ & $\begin{array}{c}\text { Penicillium } \\
\text { funiculosum }\end{array}$ & $\begin{array}{c}\text { Rhizopus } \\
\text { stolonifer }\end{array}$ & $\begin{array}{c}\text { Fusarium } \\
\text { oxysporum }\end{array}$ & $\begin{array}{c}\text { Consortium } \\
\text { Fungi }\end{array}$ \\
\hline 0 & 100.0 & 100.0 & 100.0 & 100.0 & 100.0 & 100.0 \\
\hline 3 & 6.3 & 17.6 & 20.4 & 21.0 & 21.4 & 23.4 \\
\hline 7 & 7.8 & 46.6 & 31.0 & 32.6 & 34.6 & 40.0 \\
\hline 11 & 8.7 & 67.0 & 63.0 & 58.0 & 67.8 & 70.0 \\
\hline 15 & 11.2 & 84.0 & 79.6 & 69.9 & 79.9 & 86.4 \\
\hline
\end{tabular}

Table.3 Variation in $\mathrm{PO}_{4}$ content among the various experimental setups

\begin{tabular}{|c|r|r|r|r|r|r|}
\hline Days & Control & $\begin{array}{c}\text { Aspergillus } \\
\text { fumigatus }\end{array}$ & $\begin{array}{c}\text { Penicillium } \\
\text { funiculosum }\end{array}$ & $\begin{array}{c}\text { Rhizopus } \\
\text { stolonifer }\end{array}$ & $\begin{array}{c}\text { Fusarium } \\
\text { oxysporum }\end{array}$ & $\begin{array}{c}\text { Consortium } \\
\text { Fungi }\end{array}$ \\
\hline 0 & 100.0 & 100.0 & 100.0 & 100.0 & 100.0 & 100.0 \\
\hline 3 & 8.6 & 21.6 & 19.0 & 17.6 & 18.4 & 16.4 \\
\hline 7 & 11.6 & 38.4 & 42.0 & 43.0 & 46.0 & 38.4 \\
\hline 11 & 12.6 & 68.0 & 68.2 & 72.0 & 78.0 & 72.1 \\
\hline 15 & 13.6 & 80.2 & 82.6 & 84.6 & 86.4 & 85.4 \\
\hline
\end{tabular}

Table.4 Variation in BOD content among the various experimental setups

\begin{tabular}{|c|r|r|r|r|r|r|}
\hline Days & Control & $\begin{array}{c}\text { Aspergillus } \\
\text { fumigatus }\end{array}$ & $\begin{array}{c}\text { Penicillium } \\
\text { funiculosum }\end{array}$ & $\begin{array}{c}\text { Rhizopus } \\
\text { stolonifer }\end{array}$ & $\begin{array}{c}\text { Fusarium } \\
\text { oxysporum }\end{array}$ & $\begin{array}{c}\text { Consortium } \\
\text { Fungi }\end{array}$ \\
\hline 0 & 100.0 & 100.0 & 100.0 & 100.0 & 100.0 & 100.0 \\
\hline 3 & 2.3 & 19.4 & 18.4 & 16.4 & 20.2 & 30.2 \\
\hline 7 & 3.5 & 48.0 & 36.4 & 34.6 & 40.6 & 48.6 \\
\hline 11 & 4.8 & 76.4 & 72.6 & 68.0 & 70.6 & 72.2 \\
\hline 15 & 5.8 & 89.4 & 84.0 & 78.6 & 88.4 & 89.4 \\
\hline
\end{tabular}


Table.5 Variation in COD content among the various experimental setups

\begin{tabular}{|c|r|r|r|r|r|r|}
\hline Days & Control & $\begin{array}{c}\text { Aspergillus } \\
\text { fumigatus }\end{array}$ & $\begin{array}{c}\text { Penicillium } \\
\text { funiculosum }\end{array}$ & $\begin{array}{c}\text { Rhizopus } \\
\text { stolonifer }\end{array}$ & $\begin{array}{c}\text { Fusarium } \\
\text { oxysporum }\end{array}$ & $\begin{array}{c}\text { Consortium } \\
\text { Fungi }\end{array}$ \\
\hline 0 & 100.0 & 100.0 & 100.0 & 100.0 & 100.0 & 100.0 \\
\hline 3 & 3.2 & 20.4 & 21.0 & 20.6 & 20.1 & 21.4 \\
\hline 7 & 5.7 & 46.4 & 47.0 & 48.0 & 49.6 & 50.6 \\
\hline 11 & 8.0 & 70.2 & 71.0 & 72.0 & 73.2 & 74.9 \\
\hline 15 & 8.4 & 82.6 & 84.6 & 85.6 & 86.0 & 87.6 \\
\hline
\end{tabular}

In the present study, the removal of nitrates ranged between 69.9 to $84.0 \%$ with Rhizopus stolonifer recording the minimal and A. fumigatus recording the maximal removal rates. Earlier, Hwanga et al., (2007) also recorded Aspergillus sp. to record the highest nitrate removal rates when compared to other species. Similar reports were also recorded by Kshirsagar (2012) and Sivakami et al., (2014) using A. niger. Further, Sivakami et al., (2014) also recorded minimal nitrate removal with $R$. arrhizus. This finding is similar to the present observation as minimal removal rates of nitrates was recorded with $R$. stolonifer.

With regard to phosphate levels, the removal rates were found to range from 80.2 (P. funiculosum) to $84.6 \%$ ( $F$. oxysporum). Sivakami et al., (2014) recorded phosphate reduction levels ranging from 79.2 to $83.4 \%$ with the maximum reduction taking place in the experimental set up containing $P$. citrinum which is different from the observation noticed in the present study.

In the present study, the BOD levels were found to reduce from 78.6 (R. stolonifer) to $89.4 \%$ (A. fumigatus). Azab (2008) recorded BOD reduction levels to range from 67.7 to $85 \%$ using fungi, while Andleeb et al., (2010) noticed BOD levels to decrease by $66.5 \%$ in textile effluents and Kshirsagar et al., (2012), noted a decrease in levels ranging from 66.9 to $82.4 \%$. Recently, Sivakami et al., (2014) recorded a decrease in BOD levels ranging from 71.6 to $88.4 \%$; she recorded minimal decrease in BOD levels using $F$. oxysporum and maximum levels using $A$. niger. In the present study also, maximum decrease in BOD level was recorded with $A$. fumigatus.

COD levels were found to decrease in levels ranging from 82.6 (A. fumigatus funiculosum) to 85.6\% ( $F$. oxysporum). Hamdi et al., (1991), Hamdi and Radhouane (1992), Cereti et al., (2004) and Azab (2008) also recorded decrease in COD levels ranging from 35.0 -
64.0\% using A. niger. However, Kshirsagar (2012) recorded decreased COD levels ranging from 71.0 $85.5 \%$ using fungi. Thus, the results obtained in the present study are in line with those of others. Nevertheless, in the present study, it was the consortium of fungi that produced the best results. It is probable that they showed a synergistic relationship between themselves. However, this needs further study.

\section{References}

Andleeb, S., Atiq, N., Ali, M.I., Razi-UL-Hussain, R., Shafique, M., Ahmed, B, Ghumro, P.B., Hussain, M., Hameed, A. and Ahmed, S. (2010). Biological treatment of textile effluent in stirred tank bioreactor. Int. J. Agric. Biol., 12:256-260.

APHA (1998). Standard methods for the examination of water and wastewater. 18th ed. American Public Health Association, Washington, DC.

Azab, M. S. (2008). Waste water treatment technology and environmental management using sawdust biomixture, J. Taibah Uni. Sci., 1:12-23.

BenilaSmily, J. M. (2017). Studies on fresh water fungal diversity in subtropical lakes and efficacy of indigenous fungi in waste management. Ph.D. Thesis, Bharathidasan University, Tiruchirappalli. 2017.

Boulanger, M., Malle, N. and Van Haluwyn, C. (2010). Complement au compterendu de la sessionlichénologique sur le littoral duPas-de Calais enmai 2008. Bulletin d'informations de l'Association francaise de lichenologie, 35: 97-99.

Cereti, C.F., Rossini, F., Fcderici, F., Quarantin, D., Vassile, N. and Fenice, M. (2004). Reuse of microbially treated olive mill wastewater as fertilizer for Wheat (Triticum durumDesf.). Bioreso. Technol., 91:135-140.

Chandrashekar, K.R. and Kaveriappa, K.M. (1988). Production of extracellular enzymes by aquatic hyphomycetes. Folia Microbiologica, 33:55-58. 
Cooke, W.B. (1976). Fungi in Sewage:In: Present Advances in Aquatic Microbiology. (Ed. E.B.G. Jones).Elek Science, London, pp.389-434.

Hamdi, M. and Radhouane, E. (1992). Bubble column fermentation of olive mill wastewaters by Aspergillus niger. J. Chem. Techno. Bio technol., 54:331-335.

Hamdi, M., Khadir, A. and Garcia, J. (1991). The use of Aspergillus niger for the bioconversion of olive mill waste-waters. Appl. Microbi. Biotechnol, 34:828831.

Hwanga, S. C., Lin, C. S., Chen, I. M. and Wu, I. M. (2007). Removal of nitrogenous substances by Aspergillus nigerin a continuous stirred tank reactor (CSTR) system. Aquacult. Engineer., 36: 177-183.

Kshirsagar, A. D. and Gunale, V.R. (2011). Pollution status of river Mula (Pune city) Maharashtra, India.

J. Ecophysio. and Occupati. Hlth., 11:81-90.

\section{How to cite this article:}

Anbalagan R. and Sivakami R. 2017. Biodegradation of Domestic Waste Water using Fresh Water Thermophilic Fungi Isolated from Mayanur Dam, Tamil Nadu, India. Int.J.Curr.Res.Aca.Rev. 5(11), 48-52.

doi: https://doi.org/10.20546/ijcrar.2017.511.009
Kshirsagar, A.D., Ahire, M.L. and Gunale, V.R. (2012). Phytoplankton diversity related to pollution from Mula River at Pune City. Terrestrial and Aquatic environment. Toxico., 6: 136-142.

Singh, N. (1982). Cellulose decomposition by some tropical aquatic hyphomycetes. Transactions of the British Mycological Society, 79: 560-561.

Sivakami, R., Sirajunisha, V., Abdul Kader, K. and Prem Kishore, G. (2014). Experimental studies on biodegradation of domestic waste using thermophilic fungi. International Journal of Current Research, 6: 4475-4478.

Suberkropp, K. and Klug, M.J. (1980). The maceration of deciduous leaf litter by aquatic hyphomycetes. Canadian Journal ofBotany, 50: 1025-1031. 